\title{
Investigating financial opportunities for traditional clothing industry in South Asia based on an analysis of internationally diversified portfolio using ARCH and GARCH models
}

DOI: 10.35530/IT.072.06.20202

IMRAN ALI ZULFIQAR

RAMONA BIRAU

CRISTI SPULBAR

ABDULLAH EJAZ

LUCIAN CLAUDIU ANGHEL

RADU CĂTĂLIN CRIVEANU

\begin{abstract}
REZUMAT
Investigating financial opportunities for traditional clothing industry in South Asia based on an analysis of internationally diversified portfolio using ARCH and GARCH models

This paper investigates the benefits of forming an internationally diversified portfolio in the stock markets of Bangladesh, India and Pakistan using the stock market indices data from April 2013 to March 2020. The portfolio comprises of three stock market indices from Pakistan, India and Bangladesh. The goal is to identify financial opportunities for traditional clothing industry in South Asia. Bangladesh, India and Pakistan are neighbouring countries in South Asia. Tradition, culture and specific ethnic elements influence traditional clothing in the case of the selected country cluster consisting of Bangladesh, India and Pakistan. Our empirical results indicate that internationally diversified portfolio does not reduce the risk due to global market integration in the background. Furthermore, ARCH and GARCH models reveal that large change in conditional variance is followed by large changes in conditional variance whereas small change in conditional variance is followed by small changes in conditional variance.
\end{abstract}

Keywords: traditional clothing, textile industry, portfolio diversification, South Asia, financial opportunities, stock markets

Investigarea oportunităților financiare pentru industria de îmbrăcăminte tradițională din Asia de Sud pe baza unei analize a portofoliului internațional diversificat aplicând modelele ARCH și GARCH

Acest articol de cercetare investighează beneficiile unui portofoliu internațional diversificat privind piețele bursiere din Bangladesh, India și Pakistan folosind datele colectate ale indicilor bursieri selectați din aprilie 2013 până în martie 2020. Portofoliul cuprinde trei indici bursieri din Pakistan, India și Bangladesh. Obiectivul este identificarea oportunităților financiare pentru industria de îmbrăcăminte tradițională din Asia de Sud. Bangladesh, India și Pakistan sunt țări vecine din Asia de Sud. Tradiția, cultura și elementele etnice specifice influențează îmbrăcămintea tradițională în cazul clusterului de țări selectat format din Bangladesh, India și Pakistan. Rezultatele noastre empirice indică faptul că portofoliul diversificat la nivel internațional nu reduce riscul din cauza integrării pieței globale. În plus, modelele $A R C H$ și GARCH arată că schimbările ample ale varianței condiționate sunt urmate de modificări semnificative ale varianței condiționate, în timp ce o modificare nesemnificativă a varianței condiționate este urmată de modificări reduse ale varianței condiționate.

Cuvinte-cheie: îmbrăcăminte tradițională, industria textilă, diversificarea portofoliului, Asia de Sud, oportunități financiare, piete bursiere

\section{INTRODUCTION}

India, Bangladesh and Pakistan are closely interconnected based on various elements such as nearly identical cultural heritage, traditions, linguistic values, ethnicity, geographical location, natural resources, climate, large population, traditional clothing, but also a high level of poverty. British India split in 1947 into Pakistan and India, while in 1971 due to the conflict between East Pakistan and West Pakistan, a new country emerged. In other words, India helped East Pakistan to maintain its independence as a separate state called Bangladesh. Our cluster includes three representative countries from South Asia, namely Bangladesh, India and Pakistan. Traditional clothing industry plays a very important role in the case of these neighbouring countries. Zhang et al. [1] high- lighted the fact that clothing manufacturing is rather dependent on significant institutional support in order to cope with new modern technologies. Kim [2] argued that textiles and clothing industry is a traditional sector in India with a major significance for its contributions to total exports, industrial production, and employment. Taneja et al. [3] suggested that India and Pakistan represent the leading textile trading countries worldwide, considering that bilateral trade is better well-marked in textiles compared with clothing, while cotton yarn represents the most traded textile product. Ahmed et al. [4] highlighted the fact that the fashion industry in Bangladesh includes two main components, respectively traditional clothing and modern Western apparels. Currently, clothing can be produced using performance tools like pattern design 
software, 3D scanning for anthropometric data acquisition and 2D/3D simulation, modelling and fitting software [5]. In a critical manner, Bernardes et al. [6] mentioned that most consumers claim that they are interested in sustainability aspects but still purchase "cheap" fashion. Considering all these challenges, can financial market dynamics provide growth opportunities for traditional clothing industry in South Asia, especially in the case India, Bangladesh and Pakistan?

The sub-prime credit crunch escalated in the United States from 2007 to 2008, hence, affected the financial sector of the world and particularly Europe's financial sector. The fall of financial sector has led the whole financial industry deteriorated in many parts of the world and eventually resulted into a global financial crisis 2008. The International Monetary Fund (IMF) declared financial crisis as "The Great Recession" that has revealed major flows in our financial system. Dominique Strauss-Kahn, the managing director in IMF, has urged the necessity to develop new global framework that can ascertain the better coordination of national and international policies pertaining to financial system [7]. Hence, national policies should be prepared in a way that should integrate and support international financial policies to avoid another financial crisis. Perhaps, understanding how the financial system works and how it is related to economy will also help us determining the financial policies that strengthen the economic growth. A financial system is an avenue that is a link between excess financial resources possessed by investor and public or private enterprises. This system helps economy grow and enhances the level of investors' consumption capacity. Though investment risk is shared among different parties, but they must face the market volatility. Trivedi et al. highlighted the linkage between investment opportunities and international diversification of the portfolio [8]. The relationship between investors and enterprises forms an overall financial system of the country. This financial system is more robust and efficiently achieves its objective when economy is characterised by political, economic and financial stability [9].

The episodes of increasing financial crisis in recent eras enable us to believe that the flow of capital (investors' saving) directed by the stock markets can lead to a very different dimensions other than being an efficient allocation of saving towards the best investment opportunities. The increasing speed of globalization, sometime, indicates how financial systems fail and drives the whole economy into financial crisis. The higher level of integration of financial markets on a global scale eradicates the opportunities of portfolio diversification. Such integration generates positive correlation among international stock indices returns which compromise the portfolio diversification. When international financial markets collapse, the effect rapidly spreads across emerging stock markets as well [10]. The modern portfolio theory formulated by Markowitz [11] first introduced the mathematical consideration to diversify the portfolio risk, though he cannot perfectly eliminate the risk. Through diversification method, risk can be reduced without affecting the magnitude of portfolio's expected returns. Thus, low correlated stock indices are the perfect candidates to include into portfolio formation.

Solink [12] along with other researchers, suggested that investment into international stock indices help diversify portfolio risk greater than the investment into domestic stocks but increasing speed of integration of financial markets bring in positive correlation between stock indices and benefits of investment into international stocks are decreasing [13]. Ejaz et al. [14] argued that global investors consider the opportunity of investing in the international financial markets while holding a diversified portfolio and minimizing risk. Based on the above discussion, current study aims to investigate the evolution of portfolio risk based on investment in three international stock indices. Portfolio diversification strategy represents a very important investment tool used to manage stock market risks [15]. For instance, India is a growing emerging economy [16] so has a great potential to attract investment opportunities based on the international portfolio diversification.

\section{MEASURING THE VOLATILITY OF PORTFOLIO USING ARCH AND GARCH MODELS}

Linear estimation techniques (OLS) are incapable of explaining the number of important features that are common to the financial time series.

- Leptokurtosis - The likelihood fat tails pertaining to financial time series data.

- Volatility Clustering - The tendency to stock returns volatility that appears in clusters on time series financial data. For example - the large returns of stocks, either sign, are followed by large returns and small returns of stock, either sign, are expected to have small returns in the following period. One of the explanations to volatility clustering is that the arrival of information that creates volatility clustering in the stock returns.

- Leverage effect - the likelihood of volatility to increase more following the large dip in the prices, compared to the price rise of the magnitude.

According to Compbell, Lo and Mackinlay [17], a non-linear time series is the one where the current value is correlated non-linearly to current as well as previous values of the error term $(\mu)$ :

$$
Y_{t}=f\left(\mu_{t}, \mu_{t-1}, \mu_{t-2}, \ldots\right)
$$

where $\mu_{t}$ is an independent error term and $f$ is a nonlinear function of dependent variable $Y_{t}$. A more specific form of non-linear model is as follows:

$$
Y_{t}=g\left(\mu_{t-1}, \mu_{t-2}, \ldots\right)+\mu_{t} \sigma^{2} \mu_{t-1} \mu_{t-2}
$$

where $g$ is the function of previous error term and $\sigma^{2}$ is the variance term. The $g$ is non-linear in mean with non-linear $\sigma^{2}$ variance. Any model can be linear in mean and variance (ARMA model) or can be linear in mean and non-linear in variance (GARCH model) [18]. We mostly use non-linear models such as ARCH and $\mathrm{GARCH}$ to estimate the volatility in financial data. 


\section{The Autoregressive Conditional} Heteroscedasticity Model (ARCH)

Homoscedasticity is one of most important assumptions of classical regression model, for instance, variance of error term is constant over time: $\operatorname{var}\left(\mu_{t}\right)=$ $=\sigma^{2}\left(\mu_{t}\right), \mu_{t} \sim N\left(0, \sigma^{2}\right)$. If variance of the error term is not constant over time is called heteroscedasticity which is very likely in financial time series data. Thus, it is important to select the estimator that does not assume the constant state of variance of error term and moreover, it should also ascertain that how error term variance evolves over time.

Another problem with time series financial data is volatility clustering meaning that the period of high volatility is followed by higher volatility period and period of low volatility is characterized with period of lower volatility. Using ARCH model, the time series financial data with non-constant variance in error term can be parameterized. It is also necessary to define a conditional variance of error term $\mu_{t}$ in order to understand how ARCH model works. The conditional variance of $\mu_{t}$ is represented by $\sigma^{2}$ as follows:

$$
\begin{aligned}
& \sigma_{t}^{2}=\operatorname{var}\left(\mu_{t} \mid \mu_{t-1}, \mu_{t-2}, \ldots\right)= \\
= & E\left[\mu_{t}-E\left(\mu_{t}\right)^{2} \mid \mu_{t-1}, \mu_{t-2}, \ldots\right]
\end{aligned}
$$

If $E\left(e_{t}\right)=0$, then equation 3 can we written as:

$$
\begin{gathered}
\sigma_{t}^{2}=\operatorname{var}\left(\mu_{t} \mid \mu_{t-1}, \mu_{t-2}, \ldots\right)= \\
=E\left[E\left(\mu_{t} \mid \mu_{t-1}, \mu_{t-2}, \ldots\right)\right]
\end{gathered}
$$

According to equation 4 a conditional variance of zero mean random variable $\mu_{t}$ that is normally distributed is equal to the conditional expected value of the square of $\mu_{t}$. In such a situation ARCH model is as follows:

$$
\sigma_{t}^{2}=\alpha_{0}+\alpha_{1}+\mu_{t}^{2}
$$

Equation 5 is an ARCH (1) model which shows that conditional variance of error term $\sigma_{t}^{2}$ is influenced by its immediate previous square root value. However, it should be noted that equation 5 only ascertains the part of complete model because it does not have anything to say about conditional mean. The conditional mean equation, where dependent variable $Y_{t}$ changes over time can take any form under $\mathrm{ARCH}$ model. The full ARCH model is as follows.

$$
\begin{gathered}
Y_{t}=\beta_{1}+\beta_{2} x_{2 t}+\beta_{3} x_{3 t}+\beta_{4} x_{4 t}+\mu_{t} \\
\sigma_{t}^{2}=\alpha_{0}+\alpha_{1} \mu_{t-1}^{2}
\end{gathered}
$$

where $\mu_{t} \sim N\left(0, \sigma^{2}\right)$.

Equations 6 and 7 can also be expressed in general form where variance of an error term is influenced by $k$ lags of square errors. This type of model is called $\mathrm{ARCH}(k)$.

$$
\begin{gathered}
Y_{t}=\beta_{1}+\beta_{2} x_{2 t}+\beta_{3} x_{3 t}+\beta_{4} x_{4 t}+\mu_{t} \\
\sigma_{t}^{2}=\alpha_{0}+\alpha_{1} \mu_{t-1}^{2}+\alpha_{2} \mu_{t-2}^{2}+\ldots+\alpha_{k} \mu_{t-k}^{2}
\end{gathered}
$$

where $\mu_{t} \sim N\left(0, \sigma^{2}\right)$. $\sigma_{t}^{2}$ is a conditional variance where it has positive value (a negative variance at any time is meaningless), which means that the variance regression must produce positive coefficients, for instance $\alpha_{i} \geq 0$, $(\forall) i=0,1,2, \ldots, k . \mathrm{GARCH}$ is the extension of $\mathrm{ARCH}(k)$ model.

\section{The Generalized Introgressive Conditional Heteroscedastic Model (GARCH)}

The GARCH model, developed by Bollerslev [19] and Taylor [20] estimates conditional variance that is influenced by its only previous lagged values.

Following equation is an example of conditional variance.

$$
\sigma_{t}^{2}=\alpha_{0}+\alpha_{1} \mu_{t-1}^{2}+\beta \sigma_{t-1}^{2}
$$

Equation 10 is a $\operatorname{GARCH}(1 / 1)$ model where $\alpha_{1} \mu_{t-1}^{2}$ express the information of volatility pertaining to previous period and variance during that period $\beta \sigma_{t-1}^{2}$. GARCH (1/1) model can also be written in a GARCH $(k, p)$ form where conditional variance is influenced by $k$ lags of squared errors and $p$ lags of conditional variances.

$$
\begin{aligned}
\sigma_{t}^{2}= & \alpha_{0}+\alpha_{1} \mu_{t-1}^{2}+\alpha_{2} \mu_{t-2}^{2}+\ldots+\alpha_{k} \mu_{t-k}^{2}+ \\
& +\beta_{1} \sigma_{t-1}^{2}+\beta_{2} \sigma_{t-2}^{2}+\ldots+\beta_{p} \sigma_{t-p}^{2}
\end{aligned}
$$

Equation 11 can be rearranged as:

$$
\sigma_{t}^{2}=\alpha_{0}+\sum_{i=1}^{k} \alpha_{i} \mu_{t-i}^{2}+\sum_{j=1}^{p} \beta_{j} \sigma_{t-j}^{2}
$$

GARH (1/1) model is mostly estimated and sufficient to estimate the evolution of volatility as GARH (1/1) model is as good as ARCH (2) and GARCH $(k, p)$ is as good as ARCH $(k+p)$ model [21]. Moreover, GARCH models are conditionally heteroskedastic, while are characterized by constant unconditional variance [22].

On the other hand, it is important to highlight the fact that emerging stock markets are distinguished by certain characteristic features such as: "systemic vulnerability, lofty volatility, embryonic trading mechanisms, problems related to financial regulation, nonliquidity, inadequate transparency, challenging task to access all information that are available, meagre volume trading, opportunities of diversification, different risk categories and unpredictable situations" [23].

\section{EMPIRICAL RESULTS AND DISCUSSION}

This section interprets the empirical results and provides insight into the estimations using $\mathrm{ARCH}$ and GARCH models.

\section{Data and descriptive statistics}

Our sample data includes three indices namely KSE 100 index (Pakistan stock market), BSE SENSEX 30 (BSESN) (Mumbai stock market, India) and DSEX (Dhaka stock market, Bangladesh) from April 2013 to March 2020 with 1726 observations. The selection of these market indices is based on the Pearson correlation that indicates lowest correlation among these three indices (table 1). 


\begin{tabular}{|l|c|c|c|}
\hline \multicolumn{4}{|c|}{ PEARSON CORRELATION } \\
\hline \multicolumn{1}{|c|}{ Index } & $\begin{array}{c}\text { KSE 100 } \\
\text { index }\end{array}$ & $\begin{array}{c}\text { SENSEX 30 } \\
\text { (BSESN) }\end{array}$ & DSEX \\
\hline KSE 100 index & 1.000 & - & - \\
\hline SENSEX 30 (BSESN) & 0.0176 & 1.000 & - \\
\hline DSEX & 0.0185 & 0.0055 & 1.000 \\
\hline
\end{tabular}

Despite table 1 indicates lower correlation among three indices, but, Aloui [13] ascertained in his paper that correlation coefficient may not be the best indicator of financial market independence. He further states that the correlation coefficient cannot distinguish between positive (negative) and large (small) stock returns. Furthermore, Pearson correlation coefficient is calculated based upon the assumption of linear association shipping time series financial data, whereas their linkages may also take the non-linear causality forms. This problem can be resolved through transforming the data into log form which can also be applied on non-linear model. Another way to resolve this problem is to use GARCH model.

We compute the returns of these three indices through following formula:

$$
r_{i t}=\ln \left(\frac{p_{i t}}{p_{i t-1}}\right) \times 100
$$

where $r_{i t}$ is the compounded returns of stock $i$ at time $t, p_{i t}$ is current prices of stock $i$ in $t$ time and $p_{i t-1}$ is previous year prices of stock $i$ in $t$ time. Our portfolio weights composition is $50 \%$ stock from KSE 100 , $25 \%$ from SENSEX 30 (BSESN) and 25\% from DSEX. We also adopted passive portfolio approach. Table 2 shows the descriptive statistics of all three indices and portfolio. The highest returns are associated to Mumbai stock market whereas the lowest

\begin{tabular}{|l|c|c|c|c|}
\hline \multicolumn{5}{|c|}{ DESCRIPTIVE STATISTICS OF DAILY INDICES } \\
RETURNS \\
\hline Indicator & $\begin{array}{c}\text { KSE 100 } \\
\text { index }\end{array}$ & $\begin{array}{c}\text { SENSEX 30 } \\
\text { (BSESN) }\end{array}$ & DSEX & Portfolio \\
\hline Mean & -0.0165 & -0.0188 & 0.0016 & -0.0125 \\
\hline $\begin{array}{l}\text { Standard } \\
\text { Deviation }\end{array}$ & 1.0690 & 1.0499 & 0.8958 & 0.6440 \\
\hline Max & 7.3607 & 14.7851 & 6.7370 & 5.2409 \\
\hline Min & -4.3224 & -5.3139 & -9.7984 & -2.6584 \\
\hline Observation & 1726 & 1726 & 1726 & 1726 \\
\hline
\end{tabular}

returns are pertaining to Dhaka stock market. However, Dhaka stock returns are less risker than Karachi and Mumbai stock markets. The formation of portfolio based on these three indices make portfolio less risky, however, the returns are still negative due to Karachi and Mumbai negative stock returns.

Figure 1 shows the volatility of three indices and portfolio constructed based on these indices from April 2013 to March 2020. The graph 1 indicates that returns are stable over the course of sample period; however, they are subject to volatility clustering and leverage effect. For instance, KSE 100 index contain volatility clustering on April 2013, January 2016, January 2019 and January 2020. Similarly, SENSEX 30 (BSESN) is subject to volatility clustering on April 2013, January 2018 and January 2020. However, DSEX shows volatility clustering on April 2013 and January 2020. On the other hand, portfolio returns are also subject to volatility clustering April 2013, January 2016, January 2018 and January 2020. Figure 1 confirms the existence of volatility clustering in our sample indices and portfolio returns. The next step is to check whether our residuals of portfolio return contain any ARCH effect.

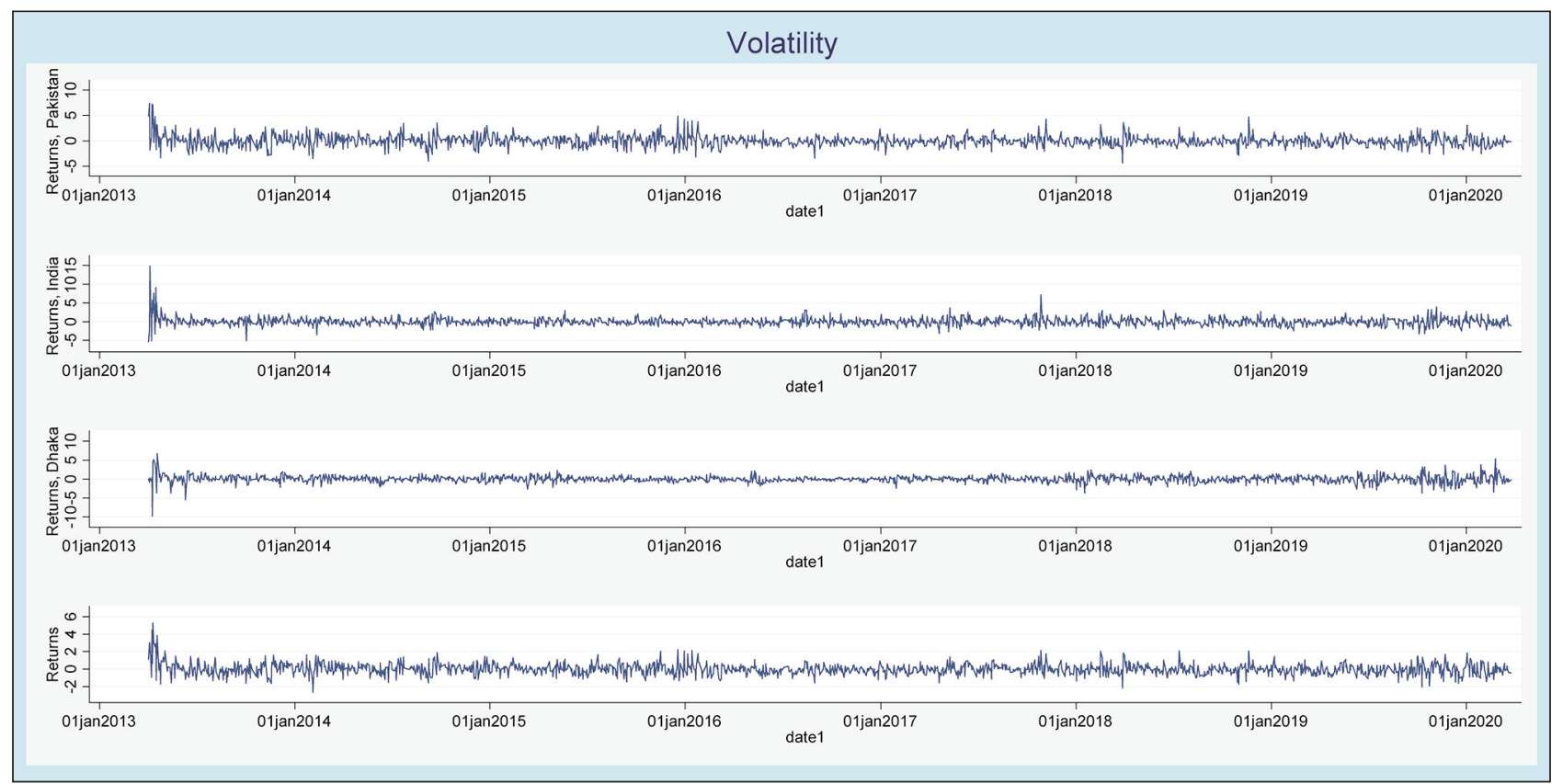

Fig. 1. Volatility of Daily Indices Returns 


\begin{tabular}{|c|c|c|c|}
\hline \multicolumn{4}{|c|}{ LM TEST FOR ARCH EFFECT IN THE RESIDUALS } \\
\hline Lags $(\mathbf{p})$ & Chi2 & Df & Prob > Chi2 \\
\hline 1 & 87.919 & 1 & 0.0000 \\
\hline
\end{tabular}

Table 3 shows the results of LM test for ARCH model with lag (1). LM test has null hypothesis i.e. $\left(\mathrm{H}_{0}\right)$ "no ARCH effect in the residuals" and alternative $\left(\mathrm{H}_{1}\right)$ "ARCH(p) disturbance in the residuals". The LM test produces $p$-value which is less than 0.05 which rejects the $\mathrm{H}_{0}$ and accepts $\mathrm{H}_{1}$ that establishes the residuals of portfolio returns contain volatility clustering and subject of $\mathrm{ARCH}$ effect.

\section{Estimation results of $\mathrm{ARCH}$ and $\mathrm{GARCH}$ model}

Table 4 shows ARCH (1/1) and GARCH (1/1) results using $\mathrm{ARCH}$ method. The ARCH and $\mathrm{GARCH}$ model show the internal effect of time series of portfolio returns. The coefficients of squared errors and conditional variance are statistically significant at $5 \%$ and $1 \%$ level of significance, respectively. The coefficient of $\mathrm{ARCH}$ model is significant at $1 \%$ level that means that previous day's information pertaining to portfolio

Table 4

\begin{tabular}{|l|c|c|}
\hline \multicolumn{3}{|c|}{ MEAN MODEL AND VARIANCE MODEL OF ARCH } \\
\hline \multirow{3}{*}{ VARIABLES } & (1) GARCH \\
\cline { 2 - 3 } & Portfolio & ARCH \\
\hline \multicolumn{3}{|c|}{ Portfolio (Mean Model) } \\
\hline Constant & $\begin{array}{c}-0.0294^{* *} \\
(0.0358)\end{array}$ & - \\
\hline \multicolumn{3}{|c|}{ Variance Model } \\
\hline Constant & - & $\begin{array}{c}0.0094 \\
(0.7625)\end{array}$ \\
\hline L. ARCH & - & $\begin{array}{l}0.1927^{* * *} \\
(0.0000)\end{array}$ \\
\hline L. GARCH & - & $\begin{array}{l}0.7847^{* * *} \\
(0.0000)\end{array}$ \\
\hline Observations & 1,726 & 1,726 \\
\hline
\end{tabular}

Note: pval in parentheses, ${ }^{* * *} p<0.01,{ }^{* *} p<0.05,{ }^{*} p<0.1$.

Table 5

\begin{tabular}{|c|c|c|c|c|}
\hline \multicolumn{5}{|c|}{ CORRELOGRAM } \\
\hline LAG & AC & PAC & Q & Prob>Q \\
\hline 1 & 0.2216 & 0.2216 & 84.877 & 0 \\
\hline 2 & 0.1027 & 0.0575 & 103.13 & 0 \\
\hline 3 & 0.0935 & 0.0645 & 118.27 & 0 \\
\hline 4 & 0.0995 & 0.0654 & 135.42 & 0 \\
\hline 5 & 0.1305 & 0.0957 & 164.92 & 0 \\
\hline 6 & 0.0979 & 0.0435 & 181.55 & 0 \\
\hline 7 & 0.0524 & 0.0112 & 186.33 & 0 \\
\hline 8 & 0.004 & -0.0277 & 186.35 & 0 \\
\hline 9 & 0.0179 & 0.0061 & 186.91 & 0 \\
\hline 10 & 0.0502 & 0.0354 & 191.29 & 0 \\
\hline
\end{tabular}

\begin{tabular}{|c|c|c|c|}
\hline \multicolumn{4}{|c|}{ HETEROSKEDASTICITY TEST: ARCH } \\
\hline Lags (p) & Chi2 & Df & Prob > Chi2 \\
\hline 5 & 0.000 & 5 & 1.000 \\
\hline
\end{tabular}

returns can greatly influence the current portfolio returns. Similarly, GARCH model coefficient is significant at $1 \%$ level that means previous days volatility of portfolio returns greatly affect the present day's volatility of portfolio returns. Hence, table 4 shows period of high volatility is followed by period of higher volatility and period of small volatilities are also followed by period of smaller volatility.

To validate the result of table 4 we run the correlogram of squared error and $\mathrm{ARCH}$ test. The correlogram included in table 5 provides evidence that square error do not contain $\mathrm{ARCH}$ effect further which can also be confirmed through $\mathrm{ARCH}$ test in table 6.

\section{CONCLUSIONS}

It is important in the realm of financial markets to study and investigate the volatility of stock returns in a time series data as well as in the context of cross market correlations. Volatility and cross market correlation have profound implications about flow of capital or capital allocation. As, in first glance, table 1 indicates the lower level of correlation among aforementioned three indices, seemingly, portfolio formation based on these indices is a better opportunity to allocate our saving because according to the Pearson correlation Pakistan (KSE 100 index), India (SENSEX 30) and Bangladesh (DSEX) are not highly correlated and their movement are not tandem. However, our overall results reveal that international diversification does not reduce the portfolio risk. One plausible reason is the higher global integration of financial markets.

We also evaluated the internal effect of time series portfolio returns using $\mathrm{ARCH}$ and $\mathrm{GARCH}$ model in the context of international diversification. The weightage composition of portfolio formation is $50 \%$ from KSE 100 index, 52\% from SENSEX 30 index and $52 \%$ from DSEX index. We applied Engle (1982) test on portfolio returns to track any $\mathrm{ARCH}$ effect in the time series. Volatility clustering effect can also be observed through graph 1 based on portfolio returns. The volatility is persistent in April 2013, January 2016, January 2018 and January 2020. Taking ARCH effect into consideration, we were able to estimate the GARCH (1/1) model. The GARCH lag 1 coefficient (almost 0.79 ) is highly significant which indicates that conditional variance is subject to volatility and conditional variance shocks are persistent in the time series data. In other words, a large change in conditional variance is followed the period of large changes in conditional variance whereas small changes in conditional variance is followed the small changes in conditional variance. 


\title{
REFERENCES
}

[1] Zhang, M., Kong, X.X., Ramu, S.C., The transformation of the clothing industry in China, Asia Pacific Business Review, 2014, http://doi.org/10.1080/13602381.2014.990204

[2] Kim, M., Export Competitiveness of India's Textiles and Clothing Sector in the United States, Economies, 2019, 7 , 47, http://doi.org/10.3390/economies7020047

[3] Taneja, N., Ray, S., Pande, D., India - Pakistan Trade: Textiles and Clothing, Indian Council for Research on International Economic Relations, 2016, Available at: http://hdl.handle.net/11540/6700 [Accessed on April 2020]

[4] Ahmed, J.U., Chowdhury, H.K., Uddin, M.J., Ferdous, M., Sadakalo, Marketing of Traditional Fashion in the Modern Fashion Industry, In: Vision, SAGE Publications, 2014, 18, 2, 125-135, http://doi.org/10.1177/0972262914528600

[5] Popescu, G., Olaru, S., Niculescu, C., Foiași, T., Săliștean, A., New 3D to 2D design method of clothing for teenagers, In: IndustriaTextila, 2019, 70, 4, 299-302, http://doi.org/10.35530/IT.070.04.1585.

[6] Bernardes, J.P., Marques A., Ferreira, F., Nogueira, M., A new and sustainable service to slow fashion brands, In: Industria Textila, 2018, 69, 2, 152-157, http://doi.org/10.35530/IT.069.02.1528

[7] Moshirian, F., The global financial crisis and the evolution of markets, institutions and regulation, In: Journal of Banking \& Finance, 2010, 5-6

[8] Trivedi, J., Spulbar, C., Birau, R., Mehdiabadi, A., Modelling volatility spillovers, cross-market correlation and comovements between stock markets in European Union: an empirical case study, In: Business, Management and Economics Engineering, 2021, 19, 1, 70-90. https://doi.org/10.3846/bmee.2021.13588

[9] Stancu, S., Predescu, M.O., Genetic Algorithm for the Portfolio Selection Problem on the Romanian Capital Market, In: Proceedings of International Conference on Engineering an Meta-Engineering, Orlando, USA, 2010, 57-60

[10] Claessens, C., AyhanKose, M., Terrones, M.E., The global financial crisis: How similar? How different? How costly?, In: Journal of Asian Economics, 2010, 21, 247-264

[11] Markowitz, H., Portfolio Selection, In: The Journal of Finance, 1952, 7, 1, 77-91

[12] Solnik, B., Why do not diversify internationally rather than domestically, In: Financial Analyst Journal, 1974, 48-54

[13] Aloui, R., Global financial crisis, extreme interdependences, and contagion effects: The role of economic structure?, In: Jornal of Banking \& Finance, 2010, 1-11

[14] Ejaz, A., Birau, R., Spulbar, C., Buda, R., Tenea, A.C., The impact of domestic portfolio diversification strategies in Toronto stock exchange on Canadian textile manufacturing industry, In: Industria Textila, 2020, 71, 3, 1, http://doi.org/10.35530/ IT.071.02.1696

[15] Spulbar, C., Trivedi, J., Birau, R., Investigating abnormal volatility transmission patterns between emerging and developed stock markets: A case study, In: Journal of Business Economics and Management, 2020, 21, 6, 1561-1592

[16] Ullal, M.S., Spulbar, C., Hawaldar, I.T., Popescu, V., Birau, R., The impact of online reviews on e-commerce sales in India: a case study, In: Economic Research-Ekonomska Istraživanja, 2021, http://doi.org/10.1080/1331677X. 2020.1865179

[17] Campbell, J.Y., Lo, A.W., MacKinlay, A.C., The Econometrics of Financial Markets, Princeton University Press, Princeton, New Jersey, 1997, 610

[18] Brooks, C., Introductory Econometrics for Finance, Cambridge University Press, New York, 2008, 379-451

[19] Bollerslev, T., Generalized autoregressive conditional heterosceasticity, In: Journal of Econometrics, 1986, 307-327

[20] Taylor, S.J., Modelling Financial Time Series, John Wiley and Sons, Ltd., Chichester, 1986

[21] Gujarati, R.N., Basic Econometrics, Mc Graw-Hill, New York, 2004, 856-867

[22] Spulbar, C., Trivedi, J., Birau, R., Tenea, C.A., Ejaz, A., Estimating volatility spillovers, dynamic causal linkages and international contagion patterns between developed stock markets: An empirical case study for USA, Canada, France and UK, In: Annals of the „Constantin Brâncuşi” University of Târgu Jiu, Economy Series, „Academica Brâncuşi" Publisher, 2019, 3, 44-62

[23] Meher, B.K., Hawaldar, I.T., Mohapatra, L., Spulbar, C., Birau, R., The Effects of Environment, Society and Governance Scores on Investment Returns and Stock Market Volatility, In: International Journal of Energy Economics and Policy, 2020, 10, 4, 1-6, https://doi.org/10.32479/ijeep.9311

\author{
Authors: \\ IMRAN ALI ZULFIQAR ${ }^{1}$, CRISTI SPULBAR ${ }^{2}$, ABDULLAH EJAZ ${ }^{3}$ \\ RAMONA BIRAU ${ }^{4}$, LUCIAN CLAUDIU ANGHEL ${ }^{5}$, RADU CĂTĂLIN CRIVEANU ${ }^{6}$ \\ ${ }^{1}$ University of Lahore, Pakistan \\ e-mail: zulfiqaraliimran05@gmail.com \\ 2University of Craiova, Faculty of Economics and Business Administration, Craiova, Romania \\ ${ }^{3}$ Department of Anthropology, Economics and Political Science, MacEwan University, Canada \\ e-mail: ejazabdullah03@gmail.com \\ ${ }^{4}$ University of Craiova, Doctoral School of Economic Sciences, Craiova, Romania \\ e-mail: ramona.f.birau@gmail.com
}

${ }^{5}$ Faculty of Management, National University of Political Studies and Public Administration, Bucharest, Romania e-mail: lucian.anghel@facultateademanagement.ro

${ }^{6}$ Independent researcher and Associate professor, PhD e-mail: raducriv@yahoo.com

\section{Corresponding author:}

CRISTI SPULBAR

e-mail: cristispulbar7@gmail.com 